\title{
APPLICATION OF LAC DYE IN SHOE UPPER LEATHER DYEING
}

\author{
Amal Kanti DEB ${ }^{1 *}$, Md. Aftab Ali SHAIKH ${ }^{1}$, Md. Zakir SULTAN², Md. Israil Hossain RAFI ${ }^{1}$ \\ 1 Institute of Leather Engineering and Technology, University of Dhaka, Dhaka-1209, Bangladesh \\ 2Centre for Advanced Research in Sciences (CARS), University of Dhaka, Dhaka-1000, Bangladesh
}

APPLICATION OF LAC DYE IN SHOE UPPER LEATHER DYEING

ABSTRACT. Shoe upper leather samples were dyed with the natural lac dyes (byproduct of shellac and shellac products industry) extracted from washings of the stick lac by conventional methods. The aim of this research is to utilize this dye water and reveal the novel natural recipe for eco-friendly dyeing operation of shoe upper leather processing. The extraction of lac dye was carried out by using water at different temperatures. The lac dye was applied on the leather samples with and without using mordants; and three different mordants (CuSO4, FeSO4, [KAl(SO4)2]) were used following metamordanting method of dyeing. Absorbance and $\lambda$ max of all dye liquors at different time intervals were determined by UV-visible spectrophotometer. The dyestuffs exhaustion and uptake were investigated and results showed that mordanted dyeing increased the dye uptake on leather than unmordanted dyeing. The FTIR analyses samples were carried out and it was found that lac dye could be mainly composed of $-\mathrm{OH},-\mathrm{NH},>\mathrm{C}=\mathrm{C}<,>\mathrm{C}=\mathrm{O},-\mathrm{COOH}$ functional groups. The fastness properties such as fastness to washing, rubbing (dry and wet) and light of prepared leather samples were assessed. The results of color fastness of the mordanted and unmordanted leather samples showed excellent (5) and best (4-5) gray scale rating respectively.

KEY WORDS: Shoe upper leather; Natural dye; Lac dye; Stick lac; Eco-friendly; Mordant

UTILIZAREA COLORANTILOR PE BAZĂ DE RĂŞINĂ NATURALĂ LA VOPSIREA FETELOR DIN PIELE PENTRU ÎNCĂLTĂMINTE REZUMAT. Eşantioanele de piele pentru încălţăminte au fost vopsite cu coloranţi pe bază de răşină naturală (produs secundar al industriei şelacului şi a produselor din şelac) extrasă din spălarea răşinii prelevate de pe scoarţa copacilor prin metode convenţionale. Scopul acestei cercetări este de a utiliza această soluţie de colorare şi de a propune o nouă reţetă naturală pentru vopsirea ecologică pielii pentru încălţăminte. Colorantul pe bază de răşină a fost extras prin utilizarea apei la temperaturi diferite. Colorantul pe bază de răşină a fost aplicat pe eşantioanele de piele cu şi fără utilizarea mordanților, utilizându-se trei mordanţi diferiți (CuSO4, FeSO4, [KAl(SO4)2]) la vopsirea prin mordansare. S-au determinat absorbanţa şi $\lambda \max$ ale tuturor soluţiilor de colorare la intervale de timp diferite cu ajutorul spectrofotometriei în domeniul UVvizibil. S-au investigat extracţia şi absorbţia coloranţilor şi rezultatele au arătat că vopsirea prin mordansare a crescut absorbţia colorantului pe piele comparativ cu vopsirea fără mordanți. S-au examinat probele prin analiza FTIR și s-a constatat că vopselele pe bază de răşină sunt în principal compuse din grupări funcţionale $-\mathrm{OH},-\mathrm{NH},>\mathrm{C}=\mathrm{C}<,>\mathrm{C}=\mathrm{O},-\mathrm{COOH}$. Au fost evaluate proprietăţile de rezistenţă cum ar fi rezistenţa la spălare, frecare (uscată şi umedă) şi rezistenţa la lumină a probelor de piele. Rezultatele testelor de rezistenţă a culorii a probelor de piele vopsite cu şi fără mordanţi au primit calificativele excelent (5), respectiv optim (4-5) pe scara de gri.

CUVINTE CHEIE: feţe de încălţăminte din piele; colorant natural; colorant pe bază de răşină naturală; răşină prelevată de pe scoarţa copacilor; ecologic; mordant

L'APPLICATION DES COLORANTS À RESINE NATURELLE DANS LA TEINTURE DES TIGES EN CUIR POUR CHAUSSURES

RÉSUMÉ. Les échantillons de cuir pour chaussures ont été colorés avec des colorants à base de laque (sous-produit de l'industrie des gommeslaques et des produits en gomme-laque), extraite des lavages de laque en bâton par des procédés classiques. Le but de cette recherche est d'utiliser cette eau de teinture et de proposer une nouvelle recette naturelle pour l'opération de teinture écologique du cuir pour chaussures. L'extraction du colorant à base de laque a été effectuée en utilisant de l'eau à différentes températures. Le colorant à base de laque a été appliqué sur les échantillons de cuir avec et sans I'utilisation de mordants. On a utilisé trois mordants différents (CuSO4, $\mathrm{FeSO}$, [KAI(SO4)2]) suivant la méthode de la teinture mordante. L'absorbance et $\lambda$ max de toutes les liqueurs de colorants à différents intervalles de temps ont été déterminés à l'aide d'un spectrophotomètre UV-visible. L'épuisement et l'absorption des colorants ont été étudiés et les résultats ont montré que la teinture mordante a augmenté l'absorption de colorant sur le cuir par rapport à la teinture sans mordant. Les échantillons analysés par FTIR ont révélé que le colorant à base de laque sont composés principalement de groupes $-\mathrm{OH},-\mathrm{NH},>\mathrm{C}=\mathrm{C}<,>\mathrm{C}=\mathrm{O}$, $-\mathrm{COOH}$. Les propriétés de résistance telles que la résistance au lavage, au frottement (sec et humide) et à la lumière des échantillons de cuir préparés ont été évalués. La résistance des couleurs des échantillons de cuir avec ou sans mordant a été évaluée comme excellente (5) et meilleure (4-5) en niveau de gris. MOTS CLÉS : tiges cuir pour chaussures ; colorant naturel ; colorants à base de laque ; laque en bâton ; écologique ; mordant

\section{INTRODUCTION}

Dye is a coloring agent that has an affinity to the substrate and imparts color to the material on which it is applied. Color is one of the most important parameters of leather as it is the first property of the leather to be assessed by consumers. Shoe upper leather is widely used (approximately $60-70 \%$ ) for the construction of upper parts of the shoe and synthetic dyes are used abundantly in shoe upper leather dyeing. Natural dyes have been known for a long time and these dyes are derived from natural sources like plants, insects, animals and minerals. Natural dyes produce very uncommon, soothing, and soft shades as compared to synthetic dyes. On the other hand, synthetic dyes are widely available at an economical price and produce a wide variety of colors; these dyes however produce skin allergy, toxic wastes and other harmfulness to human body [1]. Therefore, natural dyes could be a potential substitute of synthetic dyes.

Lac is a momentous source of natural dye which is one of the most valuable gifts of nature to human. Brilliant red dye is produced from 
the resinous substance secreted by tiny insects on some selected both wild and cultivated host plants. Lac contains various percentages of physical components such as resin $68-90 \%$, lac dye $2-10 \%$, wax $4-6 \%$ and other materials $2-4 \%$ [2]. Lac is the parent of modern plastics and the importance of lac in the modern economy, particularly of India and Thailand, is quite considerable. The lac insect basically lives on native forest trees in South China, India, Myanmar, Vietnam, Thailand, Pakistan, Bangladesh and other countries of South-eastern Asia. Lac dye is a red colored natural dye, which is present in the body fluid of lac insect, known as Laccifer lacca [3]. This dye is a byproduct of lac industry which is generally lost during washing of sticklac in primary processing of lac.

A recent crucial issue of the leather industry is to reduce environmental pollution caused by leather processing. Different types of natural dyes have been used for leather dyeing from ancient times before the synthesis of the first chemical dye aniline by William Henry Perkin in 1856 [4]. Then synthetic dyes ruined the natural dyes industry. A number of synthetic dyes are used for leather dyeing purposes that are continuously released into the environment and caused great damage to biodiversity due to the release of large volumes of waste water containing high content of organic discharge and strong coloration. Many dyes used in leather treatment can biologically transform to toxic species and cause interference in natural photosynthesis process $[5,6]$. The effluent problems of synthetic dyes occur not only during their application in the leather and textile industry, but also during their manufacture and possibly during the synthesis of their intermediates and other raw materials [7]. Recently, most of the commercial dyes, leather and textile export houses have started re-looking to maximum possibilities of using natural dyes for dyeing purposes [8]. The use of eco-friendly and non-toxic natural dyes has become a matter of significant importance due to the increased environmental awareness to avoid some risky synthetic dyes.

Mordant is a substance used to set dyes on fabrics or tissue section by forming a coordination complex with the dye which then attaches to the fabric or tissue [9]. Mordanting can be achieved by pre-mordanting, metamordanting and post-mordanting methods of dyeing. Different types and selective mordants or their combination can be applied on leather dyeing to obtain varying color or shades, to increase the dye uptake and improve the color fastness behavior of any natural dye [10]. The effect of different natural and chemical mordants like aluminum sulfate, tartaric acid and cetrimide on bleached jute fabric, as the mordant and dye concentration are increased, there is improvement in the light fastness by 1-2 grades [11]. The present study described the extraction and application of natural lac dye in shoe upper leather dying and investigated the fastness properties of dyed leather.

\section{EXPERIMENTAL}

\section{Materials and Methods}

\section{Materials}

The raw material for the extraction of lac dye was twigs lac or stick lac which was found to grow in Chapainawabganj under the division of Rajshahi, Bangladesh. It was plucked and collected from the branches of host tree of Chapainawabganj. A piece of wet blue cow hide was used for the application of extracted lac dye during dyeing operation of shoe upper leather processing.

\section{Chemicals and Instruments}

Potassium aluminum sulfate [KAl( $\left(\mathrm{SO}_{4}\right)_{2}$, copper sulfate $\left(\mathrm{CuSO}_{4}\right)$ and ferrous sulfate $\left(\mathrm{FeSO}_{4}\right)$ of analytical grade were purchased from SigmaAldrich Co., Germany and applied as mordanting agents. Standard soap with optical brightening agent (ISO 105:1989: Co1 to Co5), IR spectroscopy grade acetone (BDH Germany) and potassium bromide (Spain) pellets were used for FTIR spectral analysis. Distilled water was used for lac dye extraction. Launder-o-meter (wash fastness tester), rub fastness tester (model STM 461, SATRA, England), Gray scale for assessing staining (ISO 105-A03:1993; BSEN 20105-A03:1995; BS 1006-A03:1990; SDC standard methods, 5th Edition A03), microprocessor $\mathrm{pH}$ meter ( $\mathrm{pH} 213$, HANNA instruments), IR Spectrometer (Model IR Prestige 21, Shimadzu Corporation), UV-visible 
spectrophotometer (Model CPS-240A, Shimadzu Corporation) were used.

\section{Extraction Process}

Extraction of natural lac dye from stick lac was carried out by using distilled water. Four steps extraction were accomplished with water at different temperatures such as $25-27^{\circ} \mathrm{C}, 35$ $40^{\circ} \mathrm{C}, 50-55^{\circ} \mathrm{C}$ and $65-70^{\circ} \mathrm{C}$, respectively. In the first step twigs and others extraneous matter were removed by hand picking, dusting and sieving. Further the stick lac was crushed into small pieces with the help of mortar and sieved to remove impurities. $100 \mathrm{~g}$ of crushed lac was measured and taken into $1000 \mathrm{~mL}$ beaker and then added $700 \mathrm{~mL}$ water at room temperature. It was stirred well for 2 to 3 hours then kept it for overnight. It was then filtered with filter paper. The dye containing lac was washed thoroughly until the water soluble dye was completely extracted. In the second step the extracted dark red dye solution was concentrated through evaporation in a water bath. The dried dye was kept in oven for 30 to 45 minutes at a temperature of $40^{\circ} \mathrm{C}$ to remove damp and moisture. The extraction of lac dye was also carried out at $35-40^{\circ} \mathrm{C}, 50-55^{\circ} \mathrm{C}$ and $65-70^{\circ} \mathrm{C}$, respectively, maintaining the same procedures mentioned above.

\section{Leather Dyeing}

Dyeing is the process of adding color to leather fibers and other materials in such a way that the coloring materials become an integral part of materials rather than a surface coating. The leather samples were dyed in two ways such as dyeing with lac dye without using mordant and with using mordant (copper sulfate, ferrous sulfate, potassium aluminum sulfate).

Crushed and sieved lac has been mixed with water at the ratio of 1:7 at room temperature. The aqueous dye solution was sieved to remove solid particles. In the second phase a piece of wet-blue cow hide was taken and operations such as acid wash, re-chroming, neutralization, re-tanning were carried out to make the leather appropriate for dyeing. The dyeing operation was carried out by using $150 \%$ lac dye solution and $100 \%$ water at $45-50^{\circ} \mathrm{C}$ for $60-90$ minutes. Then $1.5 \%$ formic acid was added and ran for 30 minutes to fix the dye molecules with leather fibers. The dyed leather sample was washed well with water and fat-liquoring was done. The mechanical operations were carried out according to conventional leather manufacture.

Mordant can be used in three different ways, such as pre-mordanting, when leather is treated with mordant before dying, metamordanting in which mordant is added during dyeing of leather and post-mordanting when leather is treated with mordant after dyeing. In this experiment meta-mordanting technique was followed by using three heavy metal mordants such as copper sulfate, ferrous sulfate and potassium aluminum sulfate. $1.5 \%$ of each mordant was used during the dyeing process. The similar dyeing procedures were maintained for the three different mordants used.

\section{Determination of Dyestuffs Exhaustion and Uptakes}

Spectroscopic measurements were carried out using UV-visible spectrophotometer (spectral region 200-800 nm) at Centre for Advanced Research in Sciences (CARS), University of Dhaka, Bangladesh. The dyestuff exhaustions of the dye bath were determined by collecting the dye liquor at different time intervals such as $0,15,30,45,60$ and 75 minutes at dyeing operations of different leather samples. The measurements of used dye liquors were carried out at $\lambda_{\max } 296 \mathrm{~nm}$ and the percentage of dyestuff exhaustions were calculated by the equation $\% E=A_{o}-A_{t} / A_{o} \times 100 \%$, where $A_{0}$ is the initial absorbance (at $\lambda_{\max }$ ) in the dye bath and $A_{t}$ is the residual dye in the dye bath within a fixed time, respectively $[12,13]$. The uptake of dyestuffs by the leather samples was calculated by the equation, $A=100$ - Exhaustion (\%E).

\section{IR Spectral Analysis}

IR analyses of powder and liquid lac dye samples were performed at the region of the wavelengths range $400-4000 \mathrm{~cm}^{-1}$. A number of peaks were found at different frequencies which helped to analyze functional groups of the dye molecule.

\section{Quality Assessment of Prepared Shoe Upper Leather}

\section{Color Fastness to Washing}

The dyed leather samples were cut into $4 \times 10 \mathrm{~cm}^{2}$ size pieces. Each piece of leather sample was covered with multi-fibers (white 
cotton cloth) by stitching. The standard soap solution was prepared by adding $5 \mathrm{~g}$ of soap per litre of water. Weight of stitched leather samples was measured and added to different steel containers then fixed in launder-o-meter having liquor ratio 50:1. Temperature and time were digitally controlled at $50^{\circ} \mathrm{C}$ and 45 minutes, which were indicated on a digital indicator. The container, in which the test samples and soap solution were, kept rotating about $40 \mathrm{rpm}$ at horizontal axis with the help of electric motor. The color change of leather sample and staining of adjacent multi-fibers were assessed with help of gray scale.

\section{Color Fastness to Light}

The dyed leather samples were exposed to direct sunlight for 72 hours then with the help of gray scale the change of shade was assessed.

\section{Color Fastness to Dry and Wet Rubbing}

Wet and dry color rub fastness test was carried out according to the standard method SATRA-PM-08. The cotton felt was prepared by dipping into boiling water for 3 minutes for wet rubbing fastness, then fixed the cotton felt with holder and applied load $1780 \mathrm{~g}$ on the machine. The number of cycle was fixed 64, 128, 256, 512 and 1024 then the machine was started. The grain side of the leather samples was repeatedly rubbed by standard cotton felt. The one edge of grain side rubbed up to 512 cycles with standard cotton felt and other adjacent edge of grain side rubbed up to 1024 cycles by reversing the standard cotton felt. The color change was visually assessed by gray scale. The color fastness was evaluated by the numerical values of grey scale as excellent 5 , best $4-5$, good 4 , average $3-4$ and poor 3 .

\section{RESULTS AND DISCUSSION}

\section{Effect of Temperature on Dye Extraction}

Effect of temperature on the extraction of lac dye was observed and found that the solid content of the lac dyestuffs reduced on increasing of temperatures. The effect of temperature on the extraction of lac dye is shown in Figure 1.

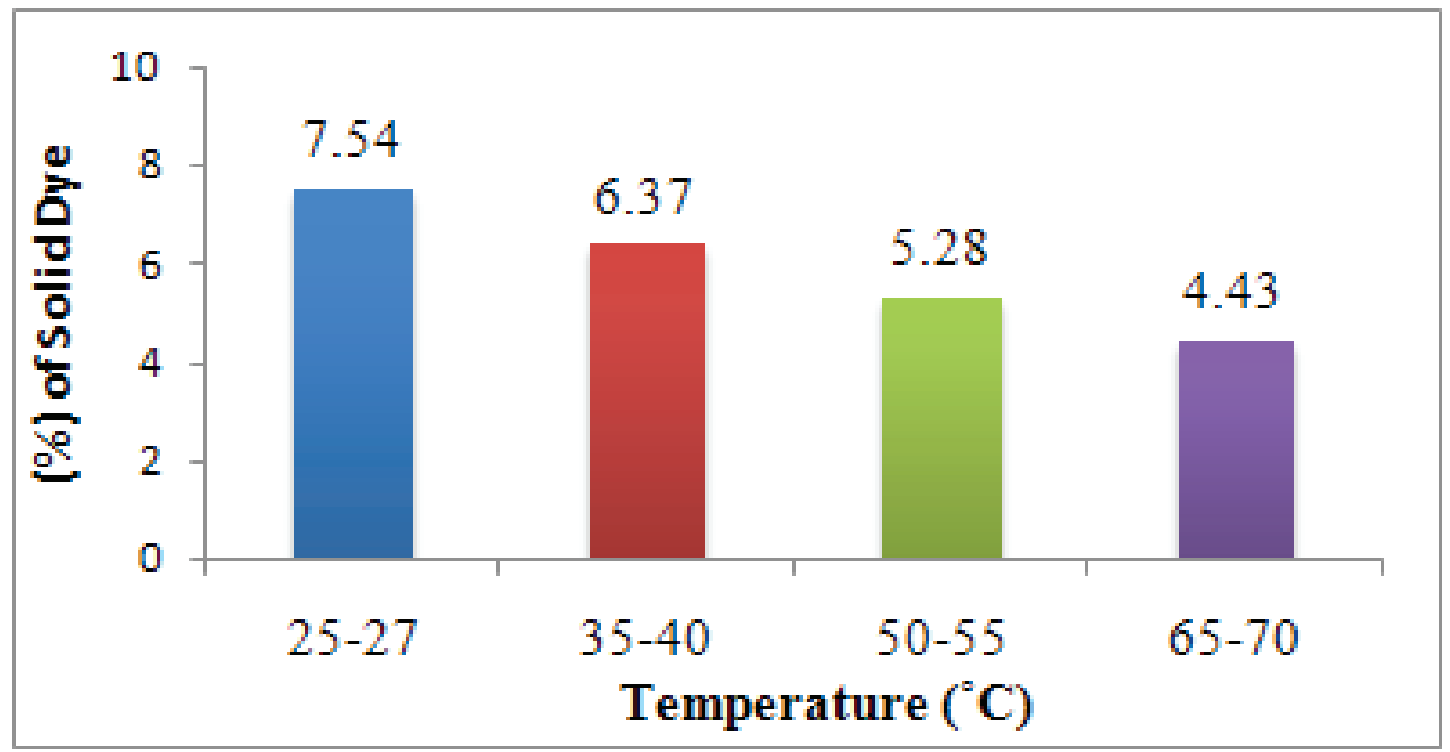

Figure 1. Effect of temperature on the extraction of lac dye

Figure 1 shows that the maximum extraction of lac dye was found at room temperature while at the minimum extraction occurred at the temperature range of 65 $70^{\circ} \mathrm{C}$. The extraction was also difficult at high temperature due to melting of major component of shellac (Aleuritic acid) present in lac dye. The solid content of extracted dye solution at room temperature was measured to be $7.54 \%$ while the solid content was reduced in case of rising temperatures gradually. The solid contents of other extracted dye solutions were $6.37 \%$ at 35 $40^{\circ} \mathrm{C}, 5.23 \%$ at $50-55^{\circ} \mathrm{C}$ and $4.43 \%$ at $65-70^{\circ} \mathrm{C}$. 


\section{Effect of Mordants in Dyeing}

Various colors were obtained depending on the mordants used which led to change in depth of the shade and produced variation in colors of the leather samples. The color of the lac dyed leather sample without mordant and leather samples dyed with copper sulfate, ferrous sulfate, and potassium aluminum sulfate mordants, respectively, are given in Table 1.

Table 1: Effect of mordants on leather samples

\begin{tabular}{clll}
\hline SL. No. & Mordant used & Color & Dyed leather samples \\
\hline Leather sample 1 & No mordant & Magenta & \\
Leather sample 2 & Copper sulfate & Dark pink & \\
Leather sample 3 & Ferrous sulfate & Light grey \\
Leather sample 4 & Potash alum & Purple red \\
\hline
\end{tabular}

\section{Dyestuffs Exhaustion and Uptake}

At the beginning of dyeing process, the initial dye concentration of dye liquor for all cases was measured to be $6.1 \mathrm{mg} / \mathrm{mL}$ and absorbance 1.25 (at $\lambda_{\max } 296 \mathrm{~nm}$ ). The results of dyestuffs exhaustion for leather dyeing with only natural lac dye and by using mordants such as potassium aluminum sulfate and ferrous sulfate at the end of 90 minutes of dyeing operation at $45-50^{\circ} \mathrm{C}$ are shown in Table 2.

Table 2: Dyestuff exhaustions of different dyed leather dye liquors

\begin{tabular}{cccc}
\hline SL. No. & Dyeing process & \% of Exhaustion & $\mathrm{pH}$ \\
\hline Leather sample 1 & No mordant & $86.42 \%$ & 5.7 \\
Leather sample 3 & Ferrous sulfate & $73.88 \%$ & 3.21 \\
Leather sample 4 & Potash alum & $77.80 \%$ & 3.76 \\
\hline
\end{tabular}

The exhaustions of dyestuffs in the dye bath were $86.42 \%$ for leather dyed with natural lac dye, $77.80 \%$ for leather dyed with lac dye and potassium aluminum sulfate, and $73.88 \%$ for leather dyed with lac dye and ferrous sulfate. Comparing the dye liquors from the three different dyeing processes, it was found that the percentage of dyestuff exhaustion of dye liquor without mordanting was the highest whereas dye liquor with ferrous sulfate mordanting showed the lowest percentage of dye exhaustion. The dye liquor with potassium aluminum sulfate mordanting gave moderate dye exhaustion. The percentage of dye uptake of different dyed leather samples are depicted in the Figures 2 and 3.
From Figure 2, it can be observed that the absorbance of dye liquor in dye bath was gradually decreased towards the end of the dyeing operation. It was happened due to the fact that the dyestuffs was gradually taken up by the leather at different intervals of time such as $0,15,30,45,60$ and 75 minutes. The absorbance values were found to be 1.252 , $0.568,0.424,0.268$, and 0.17 for the dye liquor of leather sample-1, 1.252, 0.48, 0.353, and 0.327 for the dye liquor of leather sample- 3 and $1.252,0.392,0.319,0.296,0.278$ for the dye liquor of leather sample- 4 at the same period of time intervals, respectively. The percentage of dye uptake by the leather was increased with 
time while decreased the absorbance value in the dye bath liquors. From Figure 3, the reverse phenomenon was observed and it was found that with the increasing of time the dye uptake reached the equilibrium state between the dye concentrations on the leather fibers and in the dye bath. The dye uptakes were increased gradually but in case of leather sample 1 after 30 minutes of dyeing operation, it decreased slightly and then again reached equilibrium state. The dye uptake by the leather sample 4 was higher than that of leather sample 1 and leather sample 3.

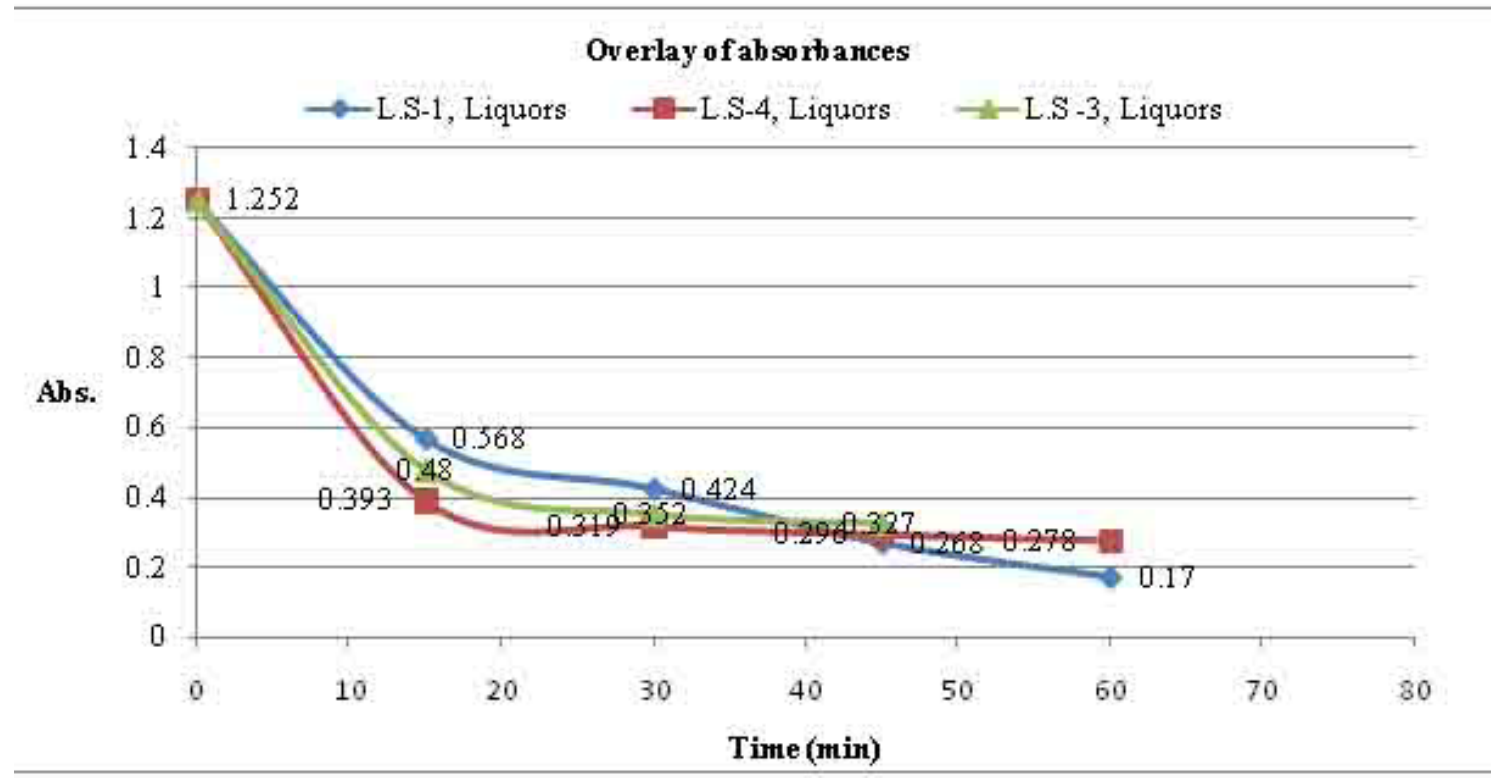

Figure 2. Absorbance peak of dye liquors overlay (L.S-1, L.S-3 and L.S-4)

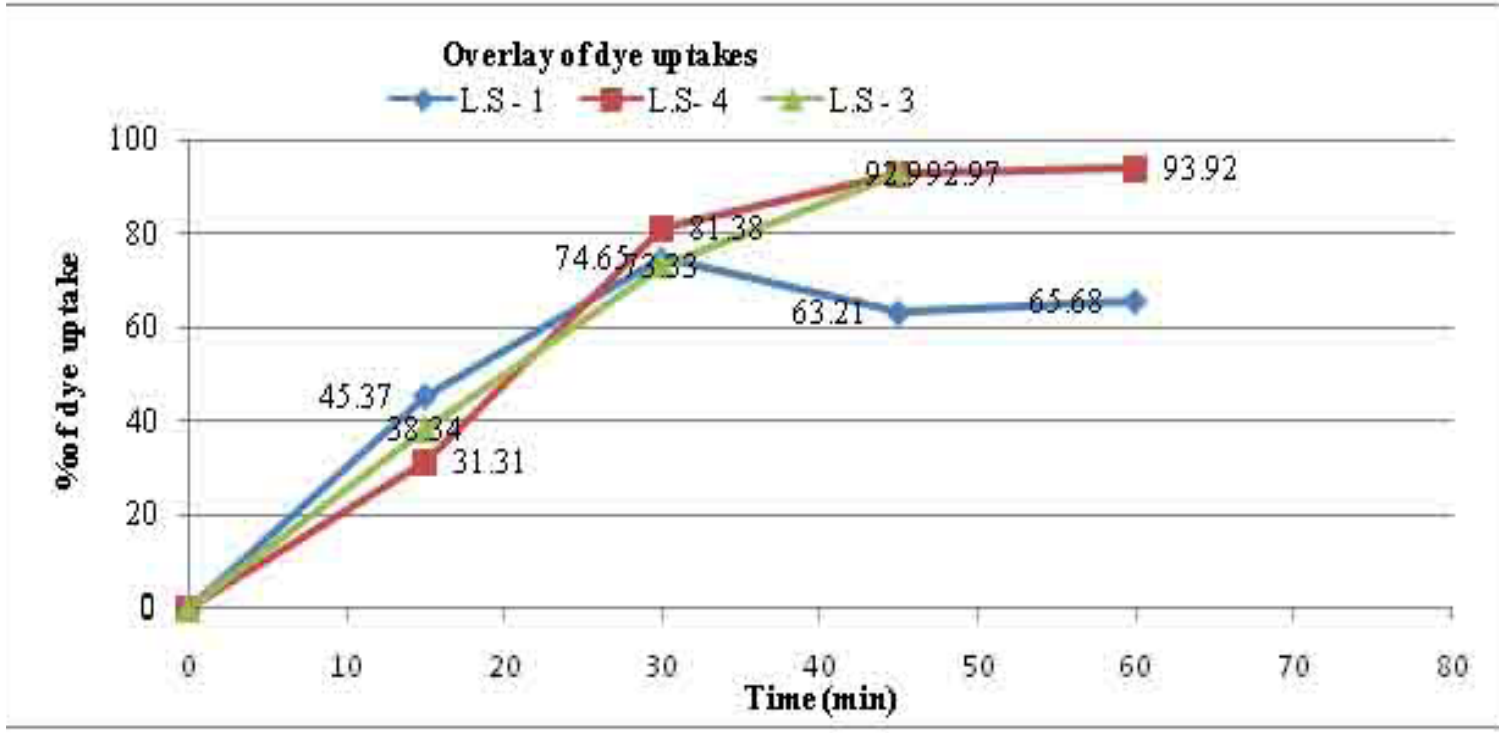

Figure 3. Percentage of dye uptake on dyed leathers overlay (L.S-1, L.S-3 and L.S-4)

\section{IR Spectral Analysis}

Tentative assignments of some IR bands of the studied compounds were carried out on the basis of standard references and those of the molecules are found out. The FTIR spectra of lac dye samples are shown in Figure 4. 

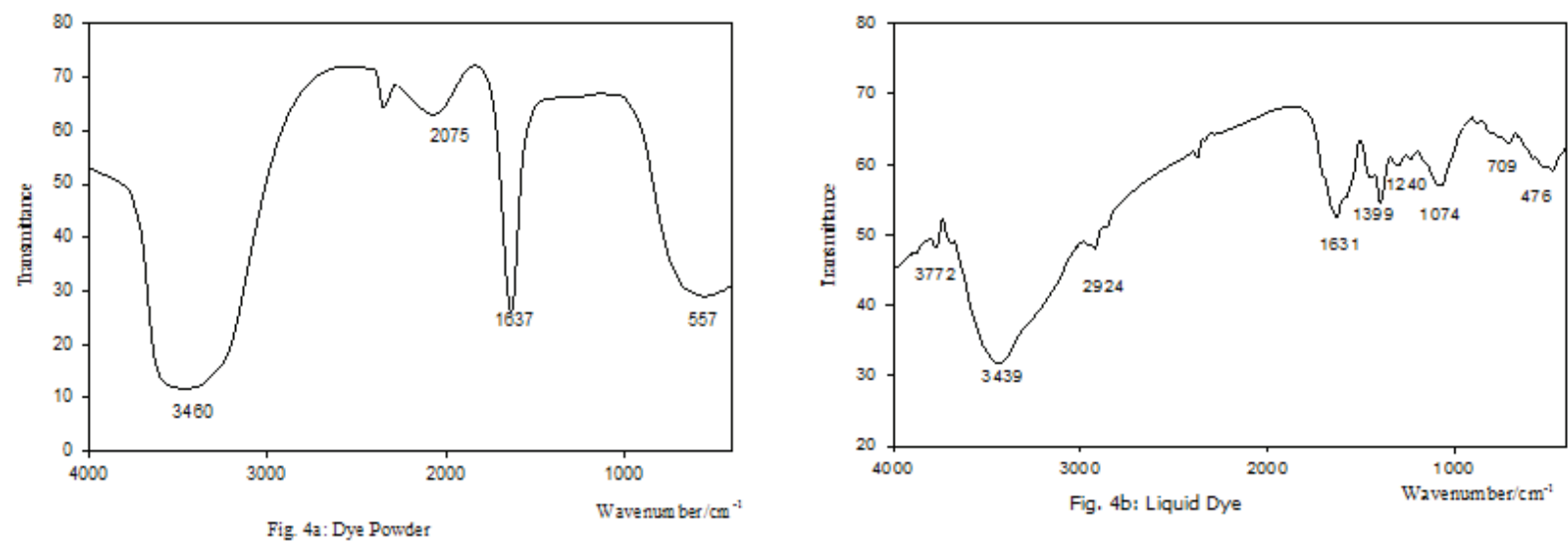

Figure 4. FTIR analysis of extracted lac dye

From the FTIR analysis, a broad peak observed between $3000 \mathrm{~cm}^{-1}$ and $3400 \mathrm{~cm}^{-1}$ could be assigned to the $\mathrm{N}-\mathrm{H}$ stretching, phenolic $\mathrm{O}-\mathrm{H}$ or $\mathrm{O}-\mathrm{H}$ of the carboxylic acid. The absorption peak observed at $2924 \mathrm{~cm}^{-1}$ was assigned to the $\mathrm{C}-\mathrm{H}$ of aliphatic or aromatic groups. The peak at 1631 was referred to the $>\mathrm{C}=\mathrm{C}$ aromatic group. The peaks between $1000 \mathrm{~cm}^{-1}$ and $1320 \mathrm{~cm}^{-1}$ were indicated to the $>\mathrm{C}-\mathrm{O}$ stretching of primary alcoholic group $(-\mathrm{CH} 2-\mathrm{OH})$ and $\mathrm{COOH}$ group, respectively $[14,15]$. The aromatic $\mathrm{C}-\mathrm{H}$ bending was observed between $675 \mathrm{~cm}^{-1}$ and $1000 \mathrm{~cm}^{-1}$ peak. The $>\mathrm{C}=\mathrm{O}$ group appeared between 1630 $\mathrm{cm}^{-1}$ to $1680 \mathrm{~cm}^{-1}$. From the IR spectral analysis, it was clearly understood that the structure of prepared lac dye could be mainly composed of $-\mathrm{OH},-\mathrm{NH}-,>\mathrm{C}=\mathrm{C}<,>\mathrm{C}=\mathrm{O},-\mathrm{COOH}$ groups.

\section{Color Fastness to Washing and Light}

The grey scale results of the color fastness to washing and light of leather dyed with lac dye and three different heavy mordants are given in Table 3.

Table 3: Color fastness to washing and light

\begin{tabular}{ccccc}
\hline & & \multicolumn{3}{c}{ Grey scale rating for } \\
SL. No. & Mordant used & \multicolumn{2}{c}{ Washing fastness } & Light fastness \\
& & White cotton cloth & Leather & \\
\hline Leather sample 1 & No mordant & 4 & $4-5$ & $4-5$ \\
Leather sample 2 & Copper sulfate & 5 & 5 & 5 \\
Leather sample 3 & Ferrous sulfate & 5 & 5 & 5 \\
Leather sample 4 & Potassium aluminum sulfate & $4-5$ & $4-5$ & 5 \\
\hline
\end{tabular}

The color fastness to washing of different leather samples dyed with extracted lac dye and different mordants were observed for both leather specimen and white cotton cloth as well. The grey scale rating of leather sample 1 was $4-5$ which assumed to be best and the corresponding white cotton cloth rating was 4 , i.e. good. The leather samples 2 and 3 which were mordanted with copper sulfate and ferrous sulfate respectively, gave excellent grey scale rating (5) for both leather and cotton fabric while the leather sample 4 which was mordanted with potassium aluminum sulfate showed little lower rating than leather samples 2 and 3 and it was $4-5$, indicating best result.

The grey scale rating of the color fastnesses to light of lac dyed leather sample with and without mordants were observed. The leather samples those were mordanted, gave excellent grey scale rating (5) while leather sample dyed 
only lac dye without using mordant showed best grey scale rating (4-5). Therefore, it can be said that the mordanting of lac dye increased the fastness properties of dyed leather.

\section{Color Fastness to Dry and Wet Rubbing}

The results of color fastness to dry and wet rubbing of different leather samples dyed with lac dye and with or without mordants are depicted in the Table 4.

Table 4: Color fastness to dry and wet rubbing

\begin{tabular}{cccccc}
\hline \multirow{2}{*}{ SL. No. } & No. of cycles & \multicolumn{2}{c}{ Grey scale rating for stain } & \multicolumn{2}{c}{ Grey scale rating for leather } \\
& & dry & wet & dry & wet \\
\hline \multirow{4}{*}{ Leather sample 1 } & 64 & 5 & 5 & 5 & 5 \\
& 124 & 5 & 5 & 5 & 5 \\
& 256 & 5 & 5 & 5 & 5 \\
& 512 & 5 & 5 & 5 & 5 \\
Leather sample 2 & 1024 & $4-5$ & 4 & $4-5$ & $4-5$ \\
& 64 & 5 & 5 & 5 & 5 \\
& 124 & 5 & 5 & 5 & 5 \\
Leather sample 3 & 256 & 5 & 5 & 5 & 5 \\
& 512 & $4-5$ & $4-5$ & 5 & 5 \\
& 1024 & $4-5$ & 4 & 5 & $4-5$ \\
& 64 & 5 & 5 & 5 & 5 \\
& 124 & 5 & 5 & 5 & 5 \\
& 256 & 5 & 5 & 5 & 5 \\
& 512 & 5 & $4-5$ & 5 & 5 \\
& 1024 & $4-5$ & $4-5$ & 5 & 5 \\
& 64 & 5 & 5 & 5 & 5 \\
& 124 & 5 & 5 & 5 & 5 \\
& 256 & 5 & 5 & 5 & 5 \\
& 512 & 5 & 5 & 5 & 5 \\
\hline
\end{tabular}

The grey scale rating of lac dyed leather sample 1 as shown in the above table for both stain and leather were found excellent rating (5) up to 512 cycles. After 1024 cycles, the grey scale ratings of stain were found to be best (4-5) at dry rubbing and good (4) at wet rubbing where as best ratings were found for leather at both dry and wet rubbing. On the other hand, color fastnesses to dry and wet rubbing of leather sample 2 was found to be excellent (5) and stain best (4-5) up to 512 cycles. After 1024 cycle the grey scale rating of leather sample 2 was showed excellent (5) at dry condition and best (4-5) at wet condition while stain was found to be best (4-5) at dry rubbing and poor (4) at wet rubbing.
It was also noticed that the leather samples 3 and 4 gave excellent (5) gray scale rating for color fastness to both dry and wet rubbing till the end of cycle. The grey scale ratings of dry and wet rubbing fastness for stain were found to be excellent (5) up to 512 cycles but in case of stain sample 3 , rating was found to be best (4-5) at wet condition whereas after 1024 cycles, the grey scale rating for stain were showed best (4-5) at both dry and wet condition. All leather samples dyed with lac dye and mordant gave best color fastness to both dry and wet rubbing and samples 3 and 4 which were mordanted with ferrous sulfate and potash alum respectively showed excellent grey scale rating. 


\section{CONCLUSION}

The experimental results revealed that lac dyes can be effectively used as a potential natural source of dyes for dyeing of leather. It gave the opportunity to produce different colors on shoe upper leather from the single color extracted lac dye using various mordants. The wash fastness, dry and wet rub fastness and light fastness grades of extracted lac dyed leather with both mordanted and unmordanted were found to be best to excellent in the grey scale rating whereas ferrous sulfate and alum mordanted dyed leather showed excellent grey scale rating. Now fast moving synthetic dyes stand as a big question before natural dyes. But the worldwide concern over the use of eco-friendly and biodegradable materials, the use of lac dyes would make its own way to reach the hearts of health conscious consumers.

The results from this study will help to underpin the future development of leather sector with respect to clean technology and environmental remediation. This may be considered as a co-partner to implement in Bangladesh upcoming government project "Green Tannery".

\section{Acknowledgement}

The authors wish to acknowledge the Centre of Advanced Research in Sciences (CARS), University of Dhaka, Bangladesh for providing the laboratory facilities to carry out the experiments.

\section{REFERENCES}

1. Nattadon, R., Rattanaphol, M., Eco-friendly of Textiles Dyeing and Printing with Natural Dyes, RMUTP, International Conference: Textile \& Fashion, Bangkok, Thailand, 2012.

2. Mukhopadhyay, B., Muthana, M.S., Lac: a Monograph, Indian Lac Research Institute, Howrah, India, Glasgow printing Co. private Ltd.. 1962, p.197.

3. Srivastava, S., Ray, D.P., Pandey, S.K., Prasad,
K.M., Prasad, M., Baboo, B., Pure Lac Dye: A Potential Natural Food Additive, International Journal of Engineering and Advanced Engineering, 2013, 3, 589-594.

4. Giles, C.H., A Laboratory Course in Dyeing, "Introduction", Third Impression, 1983, p.1.

5. Buitron, G., Gonzales, A., Characterization of the Microorganisms from an Acclimated Activated Sludge Degrading Phenolic Compound, Water Sci Technol, 1996, 34, 5-6, p.289.

6. Mohn, W.W., Martin, V.J.J.E., Yuz, T., Biochemistry and Ecology of Resin Acid Biodegradation in Pulp and Paper Mill Effluent Treatment Systems, Water Sci Technol, 1999, 40, 11-12, p.273.

7. Geetha, B., Sumathy, V.J.H., Extraction of Natural Dyes from Plants, Int J Chem Pharm Sci, 2013, 1, 8, 502-509.

8. Ashis, S.K., Adwaita, K., Dyeing of Textiles with Natural Dyes, in E.A. Kumbasar (ed.), Natural Dyes, 2011, InTech, p.29.

9. IUPAC, Compendium of Chemical Terminology, 2nd ed., "Gold Book" 1997. Online corrected version: "mordant " 1993.

10. Samanta, A.K., Priti, A., Datta, S., Dyeing of Jute and Cotton Fabrics Using Jackfruit Wood Extract: Part-I: Effects of Mordanting and Dyeing Process Variables on Colour Yield and Colour Fastness Properties, Indian J Fiber Text Res, 2007, 32, 12, 466-476.

11. Ashis, K.S.A., Priti, A., Application of Natural Dyes on Textiles, Indian J Fiber Text Res, 2009, 34, 384-399.

12. Parvinzadeh, M., Effect of Proteolytic Enzyme on Dyeing of Wool with Madder, Enzyme Microb Technol, 2007, 40, 1719-1722, https:// doi.org/10.1016/j.enzmictec.2006.10.026.

13. Paul, R., Solans, C., Erra, P., Study of Natural Dye Solubilisation in o/w Microemulsions and its Dyeing Behaviour, Colloids Surf A Physicochem Eng Asp, 2005, 253, 175-181, https://doi.org/10.1016/j.colsurfa.2004.11.003 
14. Saraswathy, G., Pal, S., Rose, C., Sastry, T.P., A Novel Bio-Inorganic Bone Implant Containing Deglued Bone, Chitosan and Gelatin, Bull Mater Sci, 2001, 24, 4, 415-420.

15. Silverstein, R.M., Webster, F.X., Spectrometric Identification of Organic Compounds, 6th ed., Wiley, New York, 1998, p.81.
(C) 2017 by the author(s). Published by INCDTPICPI, Bucharest, RO. This is an open access article distributed under the terms and conditions of the Creative Commons Attribution license (http://creativecommons.org/licenses/by/4.0/). 